\title{
The Big Five Personality as a Correlate of Involvement in Violence among Students in Secondary Schools in Nyando Sub-County, Kenya
}

\author{
Omanyo Abraham Otieno, Omae Peter Onderi, Disiye Margaret Awuor \\ Department of Psychology, Maseno University, Kenya
}

\begin{abstract}
Involvement in violence among students is a common menace not only in Nyando Sub-county, Kenya but also in the whole world. Establishing a link between the big five personality and involvement in violence could be useful in developing various personality based interventions to involvement in violence. This prompted the present study to investigate both qualitative and quantitative relationship between the big five personality and involvement in violence. The convergent parallel mixed method research design was used. A multistage random sampling was used to generate a sampling size of 418 students. A part from the students, teacher counselors and deputy head teachers were also interviewed in order to triangulate the sources of information. Both self report questionnaires and interview schedules were used to collect data. The results indicated that extraversion and neuroticism were positively correlated to violence at correlation coefficients $r=0.155$ and $r=0.102$ respectively. While agreeableness, conscientiousness and openness were negatively correlated to violence at correlation coefficients $r=-0.101, r=-$ 0.425 and $r=-0.187$ respectively. This implied that as the extroversive and neurotic tendencies rose, the levels of involvement in violence also rose in the population. Conversely as the agreeable, conscientious and openness tendencies rose, the levels of involvement in violence reduced significantly. Therefore to minimize involvement in violence, more interventional measures should be applied to people who display more of extraversion and neuroticism.
\end{abstract}

Key Words: Extraversion; Conscientiousness; Openness; Agreeableness; Neuroticism; Violence.

\section{INTRODUCTION}

I nvolvement in violence among students is a common menace not only in Nyando Sub-county, Kenya but also in the whole world as evident by different reviewed studies. According to Youth Risk Behavior Surveillance System, on top of the top six listed risky behaviors among young people in USA were behaviors that contribute to unintentional injuries and violence (CDC report, 2011). Williams (2009) in Australia reported that $14.5 \%$ of boys and $3.1 \%$ of girls were involved in violent behavior while $8.8 \%$ of boys and $3.6 \%$ of girls were involved in antisocial behaviors. Reddy (2013) in South Africa reported that over $17 \%$ of young people carried weapons and $41 \%$ had been bullied, $14 \%$ belonged to gangs, and $10 \%$ had been forced to have sex. In Kenya specifically to the study area, according to Kenya inter-Agency Rapid Assessment report (2014), about three out of five children in Nyando sub-county (62\% aged 2-14 years) were predisposed to different forms of violence and $31 \%$ abuse different forms of drugs. Inter-clan tension over political power was believed to be the source of violence. The sub-county also borders Nandi County and there had been a lot of border disputes and ethnic violence due to cattle rustling and struggle for resources (KIRA, 2014).

With regard to theoretical framework of personality, the present study adopted the Five-Factor personality model instead of the other famous models of personality because it provided one of the most elaborate explanations of personality since 1990s, with increasing evidence to support the big five traits over other models (Hirsh \& Peterson, 2008). The FiveFactor model, which was advanced by Goldberg, Costa and Mc Crae in 1990s, classifies personality into openness to experience, conscientiousness, extraversion, agreeableness and neuroticism (Paunonen \& Jackson, 2000). The broad dimension of extraversion encompasses such more specific traits as talkative, energetic, and assertive. Agreeableness includes traits like sympathetic, kind, and affectionate. Conscientiousness includes traits like organized, thorough, and planful. Neuroticism includes traits like tense, moody, and anxious. Openness to Experience includes traits like having wide interests, and being imaginative and insightful (Srivastava, 2016).

Establishing a link between the big five personality and involvement in violence could be useful in developing various personality based interventions to involvement in violence. This prompted the present study to investigate both qualitative and quantitative relationship between the big five personality and involvement in violence. The study tested the following hypotheses: $\mathbf{H}_{\mathbf{o}}$ [the null hypothesis]: There is no significant relationship between the big five personality and involvement in Violence. $\mathbf{H}_{\mathbf{A}}$ [the alternative hypothesis]: There is a significant relationship between the big five personality and involvement in Violence.

\section{METHODOLOGY}

The convergent parallel mixed method research design (Creswell, 2014) was used. A multistage random sampling was used to generate a sampling size of 418 students. A part from the students, 26 teacher counselors and 26 deputy head teachers were also interviewed in order to triangulate the sources of information. Both self report questionnaires (of 
reliability coefficient 0.880 ) and interview schedules were used to collect data. The quantitative data was analyzed using frequencies, percentages, means, standard deviations and Pearson's correlation. On the other hand, qualitative data was analyzed through content analysis. The results were presented using tables and figures.

\section{RESULTS AND DISCUSSION}

In this section the results of the study were discussed based on the four major sub-headings: response rates, demographic characteristics, distribution of responses on personality scales, distribution of responses on the violence scales, qualitative relations between personality and violence and the Pearson's correlation results.

\section{Respondents' Response Rates}

Table 1: Respondents' Response Rate Summary

\begin{tabular}{|c|c|c|c|}
\hline $\begin{array}{c}\text { Disposition of } \\
\text { Sampled Elements }\end{array}$ & $\begin{array}{c}\text { Eligible Sampled } \\
\text { Elements }\end{array}$ & $\begin{array}{c}\text { Usable } \\
\text { Responses }\end{array}$ & $\begin{array}{c}\text { Response } \\
\text { Rate }\end{array}$ \\
\hline Students & 418 & 397 & $94.98 \%$ \\
\hline Teacher Counselors & 26 & 21 & $80.77 \%$ \\
\hline Deputy Head Teachers & 26 & 22 & $84.62 \%$ \\
\hline Questionnaire Items & 40,128 & 38,112 & $94.98 \%$ \\
\hline
\end{tabular}

The respondents' response rates (students $=94.98 \%$, teacher counselors $=80.77 \%$, deputy head teachers $=84.62 \%$ ) for the study were sufficient in that they were far above the $50 \%$ bench-mark rate proposed by US Government Accountability Office (2017). This high response rate enhanced the validity and reliability of the study.

\section{Respondents' Demographic Characteristics}

In this study, several demographic characteristics of students, teacher counselors and deputy head teachers were considered. Table 2 clearly arrayed the demographic characteristics of the respondents.

Table 2: Demographic Characteristics of Respondents

\begin{tabular}{|c|c|c|c|c|}
\hline \multirow{2}{*}{ Demographic Characteristics } & \multicolumn{3}{|c|}{ Response Categories } \\
\cline { 3 - 5 } & Students & $\begin{array}{c}\text { Teacher } \\
\text { Counse } \\
\text { lors }\end{array}$ & $\begin{array}{c}\text { Deputy } \\
\text { Head } \\
\text { Teachers }\end{array}$ \\
\hline \multirow{4}{*}{$\begin{array}{c}\text { Age Brackets } \\
\text { (students) }\end{array}$} & $\begin{array}{c}\text { Below } \\
15 y r s\end{array}$ & $18(5 \%)$ & & \\
\cline { 2 - 5 } & $15-18 \mathrm{yrs}$ & $300(76 \%)$ & & \\
\cline { 2 - 5 } & $\begin{array}{c}\text { Above } \\
18 y r s\end{array}$ & $79(20 \%)$ & & \\
\hline \multirow{3}{*}{ Gender } & Male & $188(47 \%)$ & $9(43 \%)$ & $12(55 \%)$ \\
\cline { 2 - 5 } & Female & $209(53 \%)$ & 12 & $10(45 \%)$ \\
\hline \multirow{3}{*}{ Class Form } & Form 1 & $118(30 \%)$ & & \\
\cline { 2 - 5 } & Form 2 & $80(20 \%)$ & & \\
\cline { 2 - 5 } & Form 3 & $99(25 \%)$ & & \\
\cline { 2 - 5 } & Form 4 & $100(25 \%)$ & & \\
\hline Income & Low & $67(17 \%)$ & & \\
\hline
\end{tabular}

\begin{tabular}{|c|c|c|c|c|}
\hline \multirow{2}{*}{$\begin{array}{l}\text { Status of } \\
\text { students' } \\
\text { family }\end{array}$} & Medium & $319(80 \%)$ & & \\
\hline & High & $11(3 \%)$ & & \\
\hline \multirow{4}{*}{$\begin{array}{l}\text { Parenting } \\
\text { background } \\
\text { of students }\end{array}$} & $\begin{array}{c}\text { Single } \\
\text { parenthood }\end{array}$ & $84(21 \%)$ & & \\
\hline & $\begin{array}{c}\text { Divorced/s } \\
\text { eparated }\end{array}$ & $11(3 \%)$ & & \\
\hline & Orphaned & $21(5 \%)$ & & \\
\hline & $\begin{array}{l}\text { Living with } \\
\text { both } \\
\text { parents }\end{array}$ & $281(71 \%)$ & & \\
\hline \multirow{3}{*}{ School type } & Mixed & $157(40 \%)$ & $7(33 \%)$ & $8(36 \%)$ \\
\hline & Boys & $114(29 \%)$ & $7(33 \%)$ & $7(32 \%)$ \\
\hline & Girls & $126(31 \%)$ & $7(33 \%)$ & $7(32 \%)$ \\
\hline \multirow{2}{*}{$\begin{array}{l}\text { Years of } \\
\text { service }\end{array}$} & Below 5yrs & & $3(14 \%)$ & $0(0 \%)$ \\
\hline & Above 5yrs & & $\begin{array}{c}18 \\
(86 \%) \\
\end{array}$ & $\begin{array}{c}22 \\
(100 \%) \\
\end{array}$ \\
\hline \multirow{2}{*}{$\begin{array}{l}\text { Experience in } \\
\text { Counseling }\end{array}$} & Below 5yrs & & $5(24 \%)$ & $2(9 \%)$ \\
\hline & Above 5yrs & & $\begin{array}{c}16 \\
(76 \%)\end{array}$ & $20(91 \%)$ \\
\hline \multicolumn{2}{|c|}{ Total } & 397 & 21 & 22 \\
\hline
\end{tabular}

Majority of the students were in age bracket 15 - 18yrs (76\%) while few in age brackets below $15 \mathrm{yrs}(5 \%)$ and above $18 \mathrm{yrs}$ $(20 \%)$. This data was typical of high school age bracket in Kenya. The study was gender balanced for students (Male = $47 \%$, Female $=53 \%)$, teacher counselors (Male $=43 \%$, Female $=57 \%)$ and deputy head teachers (Male $=55 \%, 45 \%)$. The respondents were evenly distributed across the classes (Form $1=30 \%$, Form $2=20 \%$, Form $3=25 \%$, Form $4=$ $25 \%$ ). This implied that the views of the students were reported across all classes. The income status of the students' families was most frequent at medium income (80\%), but least for low income (17\%) and high income (3\%). Considering the parenting background of students, the students living with both parents were the most frequent in the study $(71 \%)$ followed by single parenthood $(21 \%)$ then orphaned $(5 \%)$ and divorced/separated (3\%). The school type was evenly distributed $($ Mixed $=40 \%$, Boys $=29 \%$, Girls $=$ $31 \%$ ). This implied that response was sought across all schools.

Most teacher counselors (86\%) and deputy head teachers $(100 \%)$ had adequate years of service suitable for participating in the study. Their experiences in guidance and counseling was also adequate (Teacher counselors $=76 \%$, Deputy Head teachers $=91 \%$ ) for the study. Therefore, these demographic characteristics set a strong and reliable basis for generalization of the findings to such population as documented by Connelly (2013).

\section{Distribution of Response on the Big Five Personality Scales}

This section entitled "distribution of the big five personality" described the frequency distribution of the responses on various scales of the big five personality. This section also described the assessment of normality for such distribution as a prerequisite for all parametric tests. 


\section{Distribution of Openness}

Openness to experience is one of the big five personality which sometimes is called Intellect or Intellect/Imagination. It includes traits like having wide interests, and being imaginative and insightful (Srivastava, 2016). The table 3 provided a frequency distribution of the responses on the 10 scales used in determining the levels of openness among the respondents.

Table 3: Frequency Distribution of Responses on the Openness scales

\begin{tabular}{|c|c|c|c|c|c|c|c|}
\hline Statements & \multicolumn{5}{|c|}{ Scales (Frequencies and Percentages) } & \multicolumn{2}{|c|}{ Statistics } \\
\hline 2. I have a vivid imagination and I'm inventive & $33(8 \%)$ & $47(12 \%)$ & $86(22 \%)$ & $166(42 \%)$ & $65(16 \%)$ & 3.46 & 1.147 \\
\hline $\begin{array}{l}\text { 3. I have excellent ideas and see beauty in things that } \\
\text { others might not notice. }\end{array}$ & $24(6 \%)$ & $26(7 \%)$ & $63(16 \%)$ & $183(46 \%)$ & $101(25 \%)$ & 3.78 & 1.084 \\
\hline $\begin{array}{l}\text { 5. I use difficult words and I'm curious about many } \\
\text { different things }\end{array}$ & $35(9 \%)$ & $94(24 \%)$ & $79(20 \%)$ & $125(32 \%)$ & $64(16 \%)$ & 3.22 & 1.226 \\
\hline 6. I spend time reflecting on things. & $33(8 \%)$ & $55(14 \%)$ & $46(12 \%)$ & $189(48 \%)$ & $74(19 \%)$ & 3.54 & 1.183 \\
\hline 7. I am full of ideas and formulate them clearly & $21(5 \%)$ & $37(9 \%)$ & $64(16 \%)$ & $208(52 \%)$ & $67(17 \%)$ & 3.66 & 1.033 \\
\hline $\begin{array}{l}\text { 10. I always think quickly, original and comes up with } \\
\text { new ideas }\end{array}$ & $27(7 \%)$ & $28(7 \%)$ & $59(15 \%)$ & $204(51 \%)$ & $79(20 \%)$ & 3.71 & 1.076 \\
\hline
\end{tabular}

The highest means were $3.78(\mathrm{SD}=1.084)$ and $3.78(\mathrm{SD}=$ 1.064) which resulted from the response on the statements "I have excellent ideas and see beauty in things that others might not notice" and "I am quick to understand things and a deep thinker" respectively. While the lowest mean 3.22 (SD = 1.226) resulted from the response on the statement "I use difficult words and I'm curious about many different things". Though the means $(3.32,3.46,3.78,3.22,3.54,3.66,3.62$, 3.72 , and 3.71) slightly differed from each other, the standard deviations of the responses did not differ much. This indicated same spread-outedness from the means across all the statement. And since the standard deviations were low, it was therefore clear that most responses on the statements were close to the mean responses on this scale.

From the standard deviation, the normality of the distribution was not clear hence the normal Q-Q plot as displayed in figure 1 then assessed the pictorial view of normality graphically.

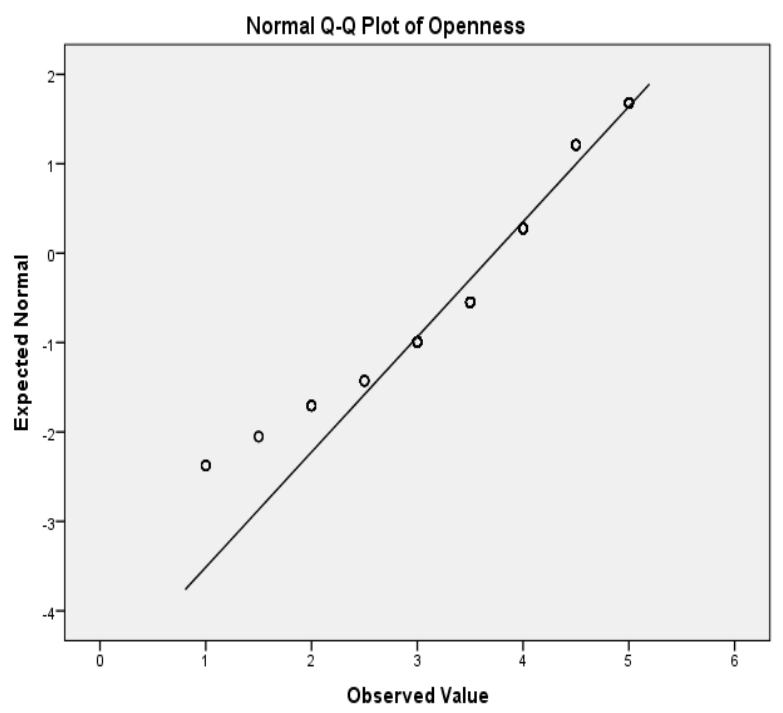

Figure 1: Normal Q-Q plot for assessing normality of Openness

The plotted points in figure 1 were tending to be closer to the line. This depicted a near normal distribution. This justified the used of parametric tests in analysis of the data related to openness (Marshall \& Samuels, 2020).

\section{Distribution of Conscientiousness}

Conscientiousness is one of the big five personality defined by the traits like being organized, thorough, and planful 
(Srivastava, 2016). The table 4 provided a frequency distribution of the responses on the 10 scales used in determining the levels of Conscientiousness among the respondents.

Table 4: Frequency Distribution of Responses on the Conscientiousness scales

\begin{tabular}{|c|c|c|c|c|c|c|c|}
\hline \multirow{2}{*}{ Statements } & \multicolumn{5}{|c|}{ Scales (Frequencies and Percentages) } & \multicolumn{2}{|c|}{ Statistics } \\
\hline & SD & $\mathrm{D}$ & $\mathrm{U}$ & A & SA & Mean & St Dev. \\
\hline $\begin{array}{l}\text { 1. I have tendency to think things through before acting } \\
\text { or speaking. }\end{array}$ & $27(7 \%)$ & $28(7 \%)$ & $31(8 \%)$ & $182(46 \%)$ & $129(31 \%)$ & 3.90 & 1.136 \\
\hline 2. I pay attention to details. & $20(5 \%)$ & $15(4 \%)$ & $25(6 \%)$ & $209(53 \%)$ & $128(32 \%)$ & 4.03 & 0.996 \\
\hline 3. I like seeing that rules are observed. & $23(6 \%)$ & $10(3 \%)$ & $29(7 \%)$ & $204(52 \%)$ & $131(33 \%)$ & 4.03 & 1.013 \\
\hline 4. I like order and self-discipline & $25(6 \%)$ & $7(2 \%)$ & $13(3 \%)$ & $88(48 \%)$ & $164(41 \%)$ & 4.16 & 1.030 \\
\hline $\begin{array}{l}\text { 5. I like following a schedule and want every detail } \\
\text { taken care of. }\end{array}$ & $21(5 \%)$ & $20(5 \%)$ & $36(9 \%)$ & $204(51 \%)$ & $116(29 \%)$ & 3.94 & 1.029 \\
\hline 6. I always makes plans and follows through with them & $22(6 \%)$ & $24(6 \%)$ & $40(10 \%)$ & $215(54 \%)$ & $96(24 \%)$ & 3.85 & 1.032 \\
\hline $\begin{array}{l}\text { 7. I get things done quickly and perseveres until the task } \\
\text { is finished }\end{array}$ & $30(8 \%)$ & $40(10 \%)$ & $53(13 \%)$ & $199(50 \%)$ & $75(19 \%)$ & 3.63 & 1.127 \\
\hline 8. I always know what I am doing. & $23(6 \%)$ & $22(6 \%)$ & $37(9 \%)$ & $200(50 \%)$ & $114(29 \%)$ & 3.91 & 1.059 \\
\hline 9. I keep things tidy and does a thorough job & $38(10 \%)$ & $39(10 \%)$ & $44(11 \%)$ & $157(40 \%)$ & $119(30 \%)$ & 3.71 & 1.258 \\
\hline 10. I always want everything to be "just right." & $27(7 \%)$ & $17(4 \%)$ & $22(6 \%)$ & $178(45 \%)$ & $153(39 \%)$ & 4.04 & 1.107 \\
\hline
\end{tabular}

The statement "I like order and self-discipline" attracted 164 responses at the highest mean response of $4.16(\mathrm{SD}=1.030)$ while the statement "I get things done quickly and perseveres until the task is finished" obtained the lowest mean response at $3.63(\mathrm{SD}=1.127)$. The standard deviations of 1.030 and 1.127 indicated that the mean of 4.16 was closer to the overall mean than that of 3.63. Therefore, the statement "I like order and self discipline" determined conscientiousness more than the statement "I get things done quickly and perseveres until the task is finished".

Generally speaking, the means, (3.90, 4.03, 4.16, 3.94, 3.85, $3.63,3.91,3.71$ and 4.04 ) if rounded off will form a whole number 4 which is equivalent to agree (A) hence most respondents agreed to the statements on this scale. Most of the standard deviations were nearly equal, an indication of a uniform flow of responses from the mean.

The nearly equal standard deviations only showed the uniform spread-outedness of the responses on conscientiousness from the means, but the normality of the distribution of responses on this scale of conscientiousness was not clear hence a pictorial view of the normality of the distribution was then assessed graphically by generating the normal Q-Q plot as displayed in figure 2 .

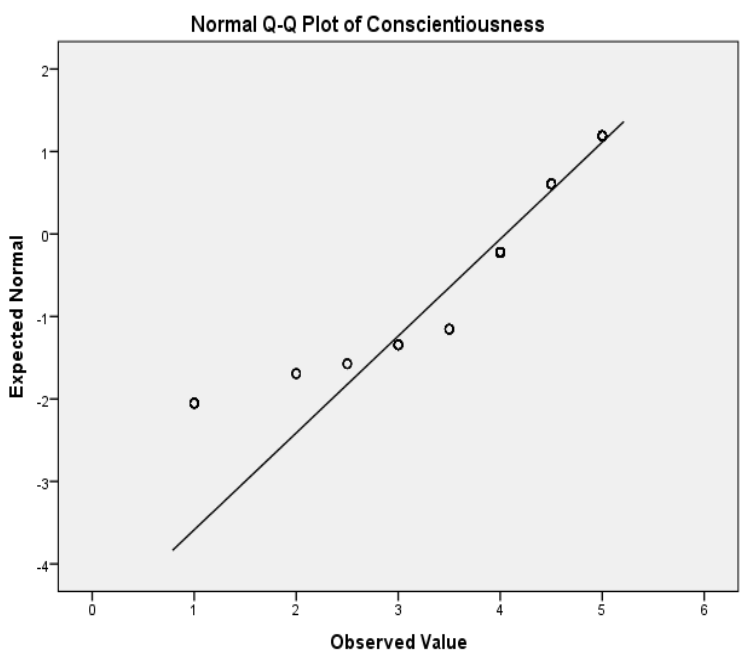

Figure 2: Normal Q-Q plot for assessing normality of Conscientiousness

The plotted points in figure 2 were tending to be closer to the line, except for the point $(1,-2)$ which appeared some distance away. This depicted a near normal distribution because only one point was far away from the line. The point $(1,-2)$ may have appeared that way because of inconsistence of responses among the respondents. This justified the used of parametric tests in analysis of the data related to conscientiousness (Marshall \& Samuels, 2020).

\section{Distribution of Extraversion}

Extraversion, a part of the big five personality also sometimes called Surgency has broad dimensions of traits. The broad dimension of extraversion encompasses such more specific 
traits as talkative, energetic, and assertive (Srivastava, 2016). In this study, 10 statements as described on the response scale

distribution of table 5 determined extraversion.

Table 5: Frequency Distribution of Responses on the Extraversion scales

\begin{tabular}{|c|c|c|c|c|c|c|c|}
\hline \multirow{2}{*}{ Statements } & \multicolumn{5}{|c|}{ Scales (Frequencies and Percentages) } & \multicolumn{2}{|c|}{ Statistics } \\
\hline & SD & D & $\mathrm{U}$ & A & SA & Mean & St Dev. \\
\hline 1. I feel comfortable around people. & $34(9 \%)$ & $29(7 \%)$ & $19(5 \%)$ & $253(64 \%)$ & $61(15 \%)$ & 3.70 & 1.087 \\
\hline 2. I always start conversations. & $26(7 \%)$ & $105(26 \%)$ & $64(16 \%)$ & $162(41 \%)$ & $40(10 \%)$ & 3.21 & 1.138 \\
\hline $\begin{array}{ll}\text { 3. I always talk to a lot of different } \\
\text { people at parties. }\end{array}$ & $62(16 \%)$ & $125(32 \%)$ & $32(8 \%)$ & $120(30 \%)$ & $58(15 \%)$ & 2.97 & 1.138 \\
\hline $\begin{array}{l}\text { 4. I don't mind being the center of } \\
\text { attention. }\end{array}$ & $71(18 \%)$ & $98(25 \%)$ & $66(17 \%)$ & $111(28 \%)$ & $51(13 \%)$ & 2.93 & 1.325 \\
\hline 5. I make friends easily. & $46(12 \%)$ & $71(18 \%)$ & $21(5 \%)$ & $180(45 \%)$ & $79(20 \%)$ & 3.44 & 1.304 \\
\hline 6. I'm outgoing and sociable & $50(13 \%)$ & $99(25 \%)$ & $64(16 \%)$ & $135(34 \%)$ & $49(12 \%)$ & 3.09 & 1.258 \\
\hline 7. I prefer the company of others & $93(23 \%)$ & $95(23 \%)$ & $50(13 \%)$ & $105(26 \%)$ & $53(13 \%)$ & 2.82 & 1.398 \\
\hline 8. I can talk others into doing things & $68(17 \%)$ & $92(23 \%)$ & $60(15 \%)$ & $124(31 \%)$ & $53(13 \%)$ & 3.01 & 1.330 \\
\hline 9. I am always the first to act. & $74(19 \%)$ & $136(34 \%)$ & $61(15 \%)$ & $85(21 \%)$ & $41(10 \%)$ & 2.71 & 1.278 \\
\hline 10. I'm excitement seeking & $41(10 \%)$ & $72(18 \%)$ & $49(12 \%)$ & $162(41 \%)$ & $73(18 \%)$ & 3.39 & 1.262 \\
\hline
\end{tabular}

The statement "I feel comfortable around people" recorded the highest mean response at $3.70(\mathrm{SD}=1.087)$ while the statement "I am always the first to act" recorded the lowest mean response at $2.71(\mathrm{SD}=1.278)$. The statement "I feel comfortable around people" was much closer to overall mean response than the statement "I am always the first to act" (by studying their standard deviations). This implied, the statement "I feel comfortable around people" defined extraversion more than the other statements. This finding was congruent with the definition of extraversion by Srivastava (2016).

Analysis of the mean responses, (3.39, 2.71, 3.01, 2.82, 3.09, $3.44,2.93,2.97,3.21$ and 3.71) indicated responses at the mid-point of the scale (3). This implied that the distribution of the extraversion was a perfect normal distribution in the population. This results could be attributed to the fact that this scale was the first to be administered hence the participants were more accurate in reporting their feelings than on the other scales.

Analysis the standard deviations, $(1.278,1.262,1.330,1.398$, $1.258,1.304,1.325,1.138$ and 1.087) depicted equal distance from the mean responses. This distribution was typical of a perfect normal distribution.

To further analyze the nature of the distribution, especially with regard to the test of normality of the distribution on the extraversion scale. The normal Q-Q plot was conducted using the explore function of the SPSS. The pictorial view of the result was as displayed in figure 3.

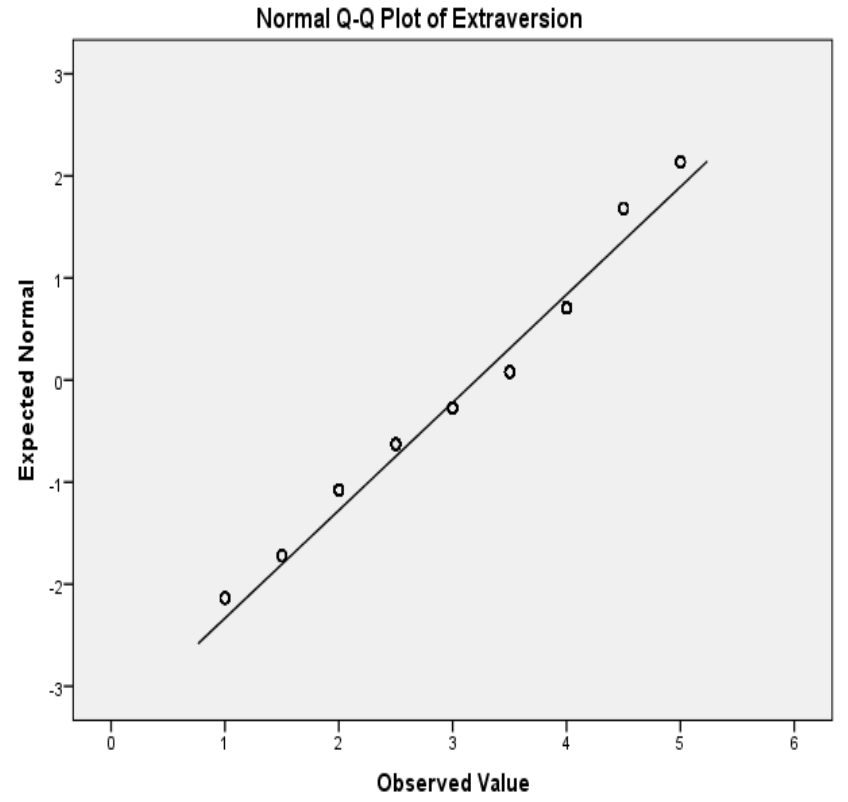

Figure 3: Normal Q-Q plot for assessing normality of Extraversion

The plotted points in figure 3 were all too close to the line. This depicted a perfect normal distribution because all points were touching the line. This justified the used of parametric tests in analysis of the data related to Extraversion (Marshall \& Samuels, 2020).

\section{Distribution of Agreeableness}

Agreeableness as one of the big five personality is defined bytraits like sympathetic, kindness, and affectionate 
(Srivastava, 2016). In this study, a group of 10 traits displayed on the scales as statements was used to determine
Agreeableness. The response on the scale of agreeableness was as tabulated in table 6 .

Table 6: Frequency Distribution of Responses on the Agreeableness scales

\begin{tabular}{|c|c|c|c|c|c|c|c|}
\hline \multirow{2}{*}{ Statements } & \multicolumn{5}{|c|}{ Scales (Frequencies and Percentages) } & \multicolumn{2}{|c|}{ Statistics } \\
\hline & SD & $\mathrm{D}$ & $\mathrm{U}$ & A & SA & Mean & St Dev. \\
\hline 1. I believe in the sincerity and good intentions of others & $50(15 \%)$ & $46(12 \%)$ & $40(10 \%)$ & $170(43 \%)$ & $91(23 \%)$ & 3.52 & 1.304 \\
\hline 2. I sympathize with others' feelings. & $44(11 \%)$ & $44(11 \%)$ & $41(10 \%)$ & $169(43 \%)$ & $99(25 \%)$ & 3.59 & 1.277 \\
\hline 3. I am helpful and unselfish with others & $36(9 \%)$ & $26(7 \%)$ & $33(8 \%)$ & $164(41 \%)$ & $137(35 \%)$ & 3.86 & 1.222 \\
\hline 4. I always take time out for others. & $46(12 \%)$ & $86(22 \%)$ & $62(16 \%)$ & $150(38 \%)$ & $53(13 \%)$ & 3.20 & 1.298 \\
\hline 5. I often feel others' emotions. & $34(9 \%)$ & $61(15 \%)$ & $53(13 \%)$ & $175(44 \%)$ & $74(19 \%)$ & 3.49 & 1.203 \\
\hline 6. I like Making people feel at ease. & $20(5 \%)$ & $40(10 \%)$ & $\begin{array}{c}54 \\
(14 \%)) \\
\end{array}$ & $196(50 \%)$ & $87(22 \%)$ & 3.73 & 1.069 \\
\hline 7. I always inquire about others' well-being. & $32(8 \%)$ & $66(17 \%)$ & $48(12 \%)$ & $165(42 \%)$ & $86(22 \%)$ & 3.52 & 1.226 \\
\hline 8. I take an interest in other people's lives. & $\begin{array}{c}104 \\
(26 \%)\end{array}$ & $\begin{array}{c}116 \\
(29 \%)\end{array}$ & $50(13 \%)$ & $88(22 \%)$ & $39(10 \%)$ & 2.60 & 1.342 \\
\hline 9. I like doing things for others. & $56(14 \%)$ & $\begin{array}{c}102 \\
(26 \%) \\
\end{array}$ & $52(13 \%)$ & $132(33 \%)$ & $55(14 \%)$ & 3.07 & 1.307 \\
\hline 10. I rarely put people under pressure. & $97(24 \%)$ & $80(20 \%)$ & $40(10 \%)$ & $119(30 \%)$ & $61(15 \%)$ & 2.92 & 1.446 \\
\hline
\end{tabular}

The statement "I am helpful and unselfish with others" had the highest mean response at $3.86(\mathrm{SD}=1.222)$ while the statement "I take an interest in other people's lives" had the lowest mean response at 2.60 (SD = 1.342). Though the means differed but the standard deviations were close. This implied the two statements were at almost equal intervals from the mean hence they were good indicators of agreeableness. Since the statements with the lowest and the highest mean were good indicators of agreeableness hence other statements were also considered good indicators of agreeableness. The statements on this scale actually described traits such as sympathetic, kindness, and affectionate which forms typical characteristics of agreeableness as reported by Srivastava (2016).

To further probe the standard deviations (ranging from 1.069 to 1.446), the variation among the statements were almost uniform as justified by the reliability statistics of the questions $(\alpha=0.880)$.

To justify the use of parametric tests on the agreeableness scales, the normality of the distribution was assessed graphically by the use of Q-Q plots. The pictorial view of the distribution was displayed in figure 4.

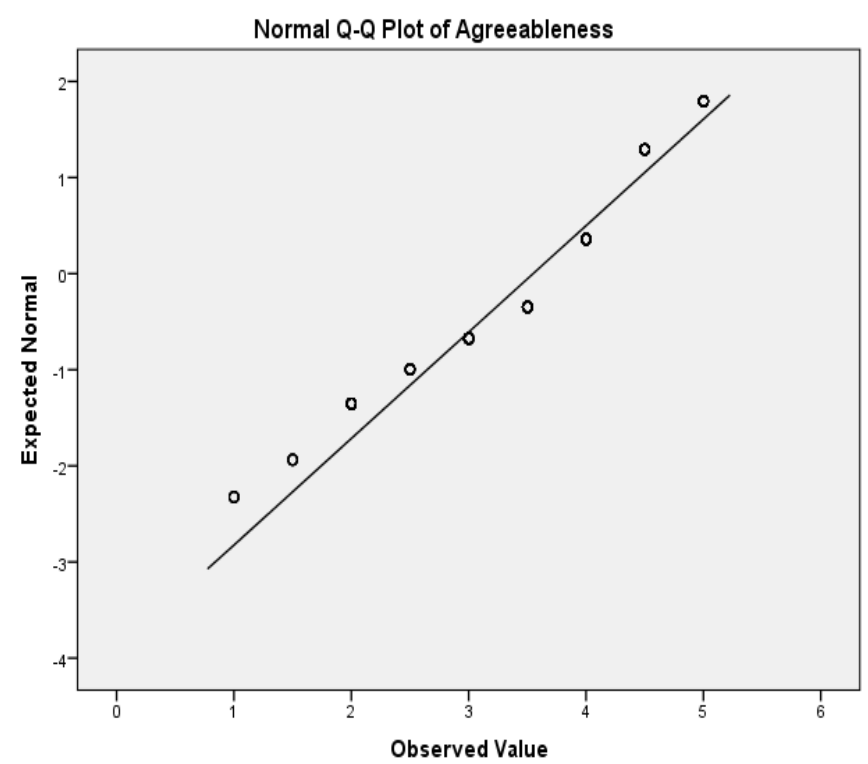

Figure 4: Normal Q-Q plot for assessing normality of Agreeableness

Since the plots were trending towards the line, a near normality was depicted hence the application of the parametric test on the distribution of agreeableness was totality justified as reflected on the literature published by Marshall and Samuels (2020).

\section{Distribution of Neuroticism}

Neuroticism is a part of the big five personality which sometimes reversed and called Emotional Stability. It includes 
traits like tense, moody, and anxious (Srivastava, 2016). In this study neuroticism was determined by 10 statements rated on a five point Likert scale as tabulated in table 7.

Table 7: Frequency Distribution of Responses on the Neuroticism scales

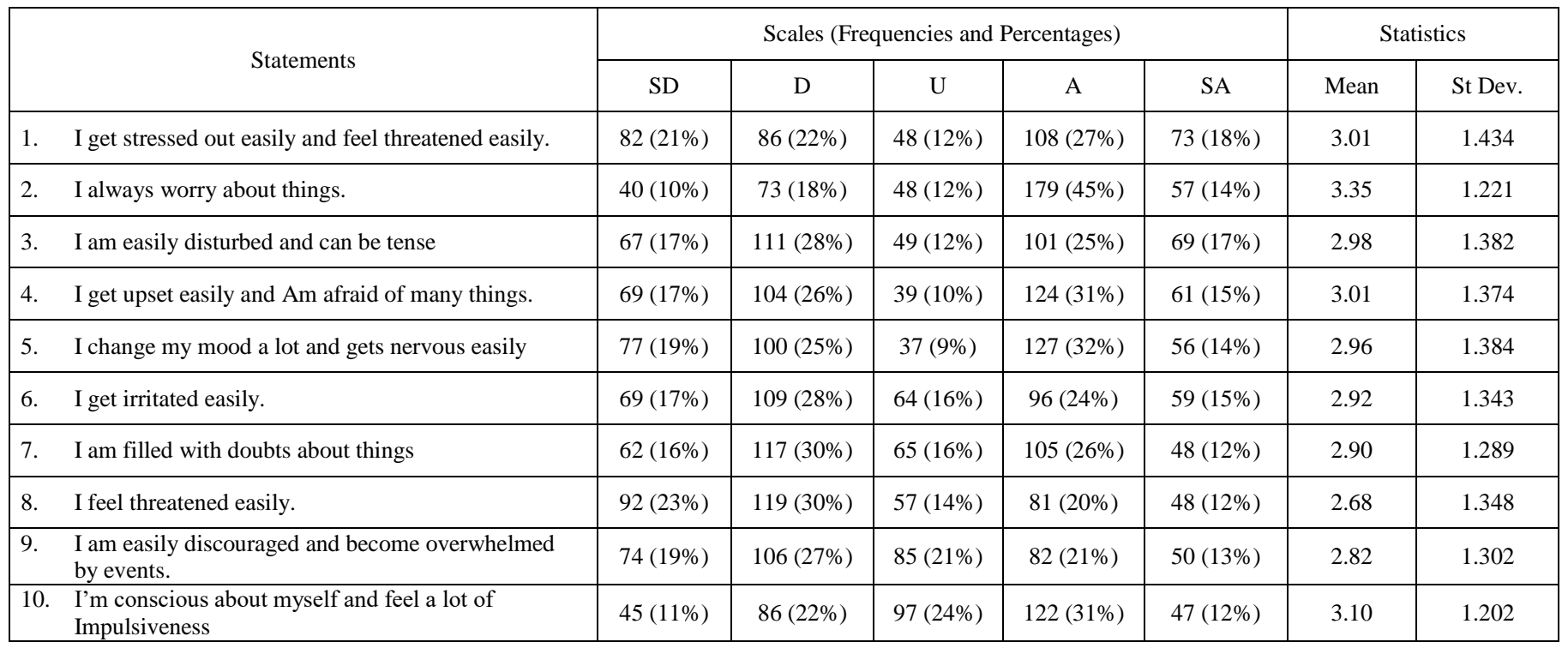

The statement "I always worry about things" recorded the highest mean response at $3.35(\mathrm{SD}=1.221)$ while the statement "I feel threatened easily" recorded the lowest mean response at $2.68(\mathrm{SD}=1.348)$. Though the highest and the lowest mean responses on the two statements differed, their standard deviations were almost equal. This indicated a nearly equal distance between the scores on the two statements hence depicted a high inter-correlatedness of the statements at large. This formed a good basis for the proof of the previously determined reliability statistics of the questionnaire $(0.880)$.

The standard deviations, (from 1.434 to 1.202) were nearly equal, depicting a distribution nearing the normal distribution. Though the standard deviations gave some light on the distribution, it could not test the normality of the distribution. The Q-Q plots was generated from the explore function of the SPSS in order to help in the assessment of normality of the distribution. The pictorial display of the normality was shown in figure 5 .

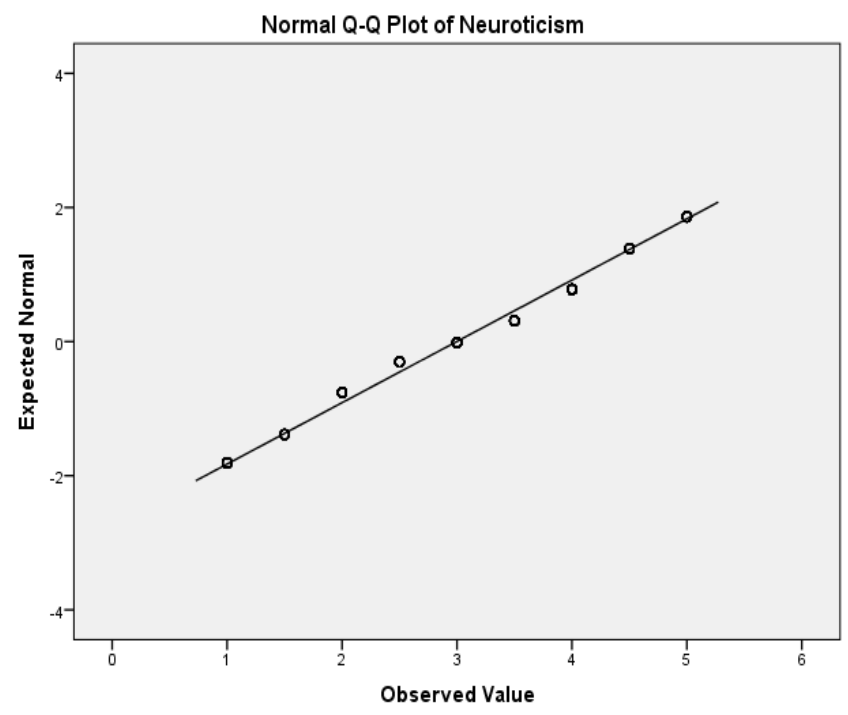

Figure 5: Normal Q-Q plot for assessing normality of Neuroticism.

The Q-Q plots for the distribution of neuroticism were joined to the line. This indicated a perfect normal distribution and a good justification for the use of parametric tests like Pearson's product moment correlation, regression analysis and ANOVA as depicted by the literature of Marshall and Samuels (2020).

\section{Distribution of Response on the Violence Scale}

Involvement in violence was determined by 10 statements rated on five point Likert scale. The descriptive function of SPSS was used to generate a frequency distribution as tabulated in table 8. 
Table 8: Frequency Distribution of Responses on the Involvement in violence scales

\begin{tabular}{|cl|c|c|c|c|c|c|c|}
\hline \multirow{2}{*}{ Statements } & \multicolumn{3}{|c|}{ Scales (Frequencies and Percentages) } & \multicolumn{2}{c|}{ Statistics } \\
\cline { 3 - 8 } & & SD & D & U & A & SA & Mean & St Dev. \\
\hline 1. & I am not afraid to carry weapons for war & $157(40 \%)$ & $80(20 \%)$ & $44(11 \%)$ & $62(16 \%)$ & $54(14 \%)$ & 2.44 & 1.473 \\
\hline 2. & $\begin{array}{l}\text { Engaging in physical fight is my healthy way of } \\
\text { solving disputes }\end{array}$ & $208(52 \%)$ & $82(21 \%)$ & $35(9 \%)$ & $29(7 \%)$ & $43(11 \%)$ & 2.04 & 1.372 \\
\hline 3. & $\begin{array}{l}\text { Destruction of property is the best way of } \\
\text { demonstrating my grievances }\end{array}$ & $194(49 \%)$ & $86(22 \%)$ & $53(13 \%)$ & $33(8 \%)$ & $31(8 \%)$ & 2.05 & 1.218 \\
\hline 4. & I like participating in violent political demos & $198(50 \%)$ & $84(21 \%)$ & $56(14 \%)$ & $26(7 \%)$ & $32(8 \%)$ & 2.02 & 1.279 \\
\hline 5. & $\begin{array}{l}\text { Engaging in violence is the best dispute resolution } \\
\text { mechanism }\end{array}$ & $213(54 \%)$ & $80(20 \%)$ & $43(11 \%)$ & $30(8 \%)$ & $31(8 \%)$ & 1.96 & 1.285 \\
\hline 6. & I like associating with peers who are violent & $163(41 \%)$ & $96(24 \%)$ & $49(12 \%)$ & $53(13 \%)$ & $36(9 \%)$ & 2.25 & 1.351 \\
\hline 7. & Retaliation is the best way of quenching my anger & $120(30 \%)$ & $97(24 \%)$ & $81(20 \%)$ & $60(15 \%)$ & $39(10 \%)$ & 2.50 & 1.323 \\
\hline 8. & $\begin{array}{l}\text { I like destroying people's property even if not } \\
\text { provoked }\end{array}$ & $251(63 \%)$ & $76(19 \%)$ & $24(6 \%)$ & $15(4 \%)$ & $31(8 \%)$ & 1.74 & 1.217 \\
\hline 9. & I like seeing people suffer or cry & $230(58 \%)$ & $89(22 \%)$ & $28(7 \%)$ & $16(4 \%)$ & $34(9 \%)$ & 1.83 & 1.248 \\
\hline 10. & $\begin{array}{l}\text { Causing pain to someone is the best way of } \\
\text { playing }\end{array}$ & $230(58 \%)$ & $91(23 \%)$ & $25(6 \%)$ & $16(4 \%)$ & $35(9 \%)$ & 1.83 & 1.254 \\
\hline
\end{tabular}

The statement "Retaliation is the best way of quenching my anger" recorded the highest mean response of $2.50(\mathrm{SD}=$ 1.323) while the statement "I like destroying people's property even if not provoked" recorded the lowest mean response of $1.74(\mathrm{SD}=1.217)$. The mean responses per statement differed greatly but the standard deviations are nearly equal. This indicated a constant variance within and between the statements. This depicted some correlatedness among the statements hence the statements formed a good basis for determining the involvement in violence.

The assessment of the normality of the distribution was done graphically by the use of the normal Q-Q plots. The explore function of the SPSS was used to generate the normal Q-Q plots as pictorially displayed in figure 6 .

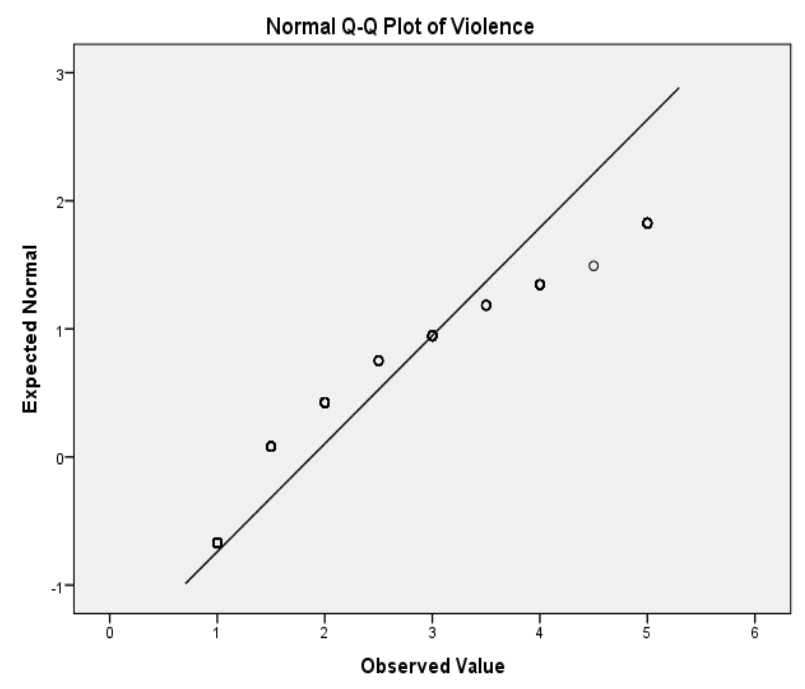

Figure 6: Normal Q-Q plot for assessing normality of Involvement in Violence.
The plots of co-ordinates $(5,2)$ and $(4.5,1.5)$ appeared far from the line, but the majority of the points were nearing the line. This depicted a moderate skewness. But still with such minimal skewness, the parametric tests can still be conducted upon transforming the variable. For the ease of analysis, the scales of risky behavior were transformed using the SPSS function transform to a single scale. This idea of transform was congruent to literature on statistics by Marshall and Samuels (2020).

\section{Qualitative Relationship between the Big Five Personality and Violence}

The qualitative relationship between the big five personality and involvement in violence was sought for by the question two of the interview schedule: "How is the big five personality related to involvement in violence among young people in this school?" Beginning with the following narrations:

\section{"The big five personality are related to involvement in violence, but it is difficult to establish the relationship verbally" [TC 8, 9, 10, 11, 12 and 13].}

"The relationship between the two exist, but it is difficult to look at it qualitatively" [DHT 4, 5, 8, 9 and 15]

Through analysis of the above narrations, six teacher counselors (TC 8, 9, 10,11, 12 and 13) and five deputy head teachers (DHT 4, 5, 8, 9 and 15), agreed with the fact that the big five personalities were related to involvement in violence but could not describe the nature of the relationship. These findings were justified by the study conducted by (Lubomir\& Jana, 2015) who reported that personality was significantly related with acute risk taking in financial sector, banking sector and everyday life. In order to improve on the above 
qualitative findings, the quantitative analysis of this relationship was further conducted.

For further probing of the respondents, the following was reported:

"Most people inclined towards extraversion speak openly and this put them at risk of involving in violence. Neurotics are venerable to violence because they normally seek a sense of belonging. Agreeable people are least venerable to violence because they are sympathetic in nature. Conscientiousness individuals display minimal tendencies to violence because they always think before they act. Open minded individuals are not predictable based on involvement in violence" [TC 1, 2, 3, 4, 5, 6, 7 and 19, and DHT 2, 3, 6, 16, 17, 18 and 20].

Analysis of the above narrative revealed that a total of fifteen teacher counselors and deputy head teachers agreed to the fact that extraverts were venerable to violence because of their out-going and sociable tendencies. They also argued that neurotics had a lot of attention seeking which expose them to violence. Agreeableness on the other hand were considered sympathetic hence were less likely to engage in violence. Conscientiousness individuals were planful and thinkers hence had minimal tendencies to violence. The openness personality was unpredictable because of their imaginative and creative nature. These findings were consistent with those of (Schmitt, 2011), (Vollrath, Knoch \& Cassano, 2012) and (Olalekan, 2014) who reported on the same findings.

For continuous inquiry on the subject matter, the following narratives were also noted:

\begin{abstract}
"Extraverted students are more likely to engage in violence than neurotic students because the extraverts are interactive and talkative while neurotics are impulsive and possess withdrawal tendencies. Agreeable students feel for their counter parts hence less likely to engage in violence. Conscientious individuals are dutiful hence display reduced tendencies to violence. Open minded individuals are not easy describing based on their levels of engagement in violence because of their way of perception which is more complex and unpredictable". [TC 18, 20, 21 and DHT 17, 18, 19, 21, 22]
\end{abstract}

According to the extract above, extraverted and neurotic individuals were most likely to engage in violence. The agreeablessness and conscientiousness had lower tendencies to violence. The openness could be evaluated based on risky behavior profile as fifty-fifty. These findings were supported by pieces of literature of (Voracek, 2012), (Heine, Buchtel \& Norenzayan, 2011) and (Joshi \&Bhardwaj, 2016) who reported extraversion and neuroticism as positively correlated with risky behaviors while conscientiousness and agreeableness as negatively correlated with risky behavior.

In conclusion, the qualitative analysis of the relationship between the big five personality and involvement in violence explained the relationship well. It even provided the direction of the relationship, but failed to show the strength or the degree of the relationship. This therefore justified the reason for conducting the subsequent quantitative analysis by the use of Pearson Product moment correlation.

\section{The Pearson Correlation Results}

The quantitative relationship between the big five personality and involvement in violence was established by using the correlate function of SPSS. The following hypotheses were tested by Pearson Product moment Correlation:

$H_{o}$ [the null hypothesis]: There is no significant relationship between the big five personality and involvement in Violence.

$H_{A}$ [the alternative hypothesis]: There is a significant relationship between the big five personality and involvement in Violence.

The Pearson correlation results were displayed in table 9.

Table 9: The Pearson Correlation results for the Relationship between the Big Five Personality and Involvement in Violence

\begin{tabular}{|c|c|c|}
\hline $\begin{array}{c}\text { Big Five } \\
\text { Personality }\end{array}$ & Statistics & $\begin{array}{c}\text { Involvement in } \\
\text { violence }\end{array}$ \\
\hline \multirow{4}{*}{ Extraversion } & $\mathrm{r}$ & 0.155 \\
\cline { 2 - 3 } & Sig. (2-tailed) & 0.002 \\
\cline { 2 - 3 } Agreeableness & $\mathrm{n}$ & 397 \\
\cline { 2 - 3 } & $\mathrm{r}$ & -0.101 \\
\cline { 2 - 3 } Conscientiousness & Sig. (2-tailed) & 0.044 \\
\cline { 2 - 3 } & $\mathrm{n}$ & 397 \\
\cline { 2 - 3 } & Sig. (2-tailed) & -0.425 \\
\cline { 2 - 3 } & $\mathrm{n}$ & 0.000 \\
\hline \multirow{4}{*}{ Neuroticism } & $\mathrm{r}$ & 397 \\
\cline { 2 - 3 } & Sig. (2-tailed) & 0.102 \\
\cline { 2 - 3 } & $\mathrm{n}$ & 0.042 \\
\hline \multirow{4}{*}{ Openness } & $\mathrm{r}$ & 397 \\
\cline { 2 - 3 } & Sig. (2-tailed) & 0.187 \\
\cline { 2 - 3 } & $\mathrm{n}$ & 397 \\
\hline
\end{tabular}

The correlation is significant at the 0.05 level (2-tailed)

According to Blalock (2012), the degree or the strength of correlation is explained as: for values of correlation coefficient $r=+1$ or -1 , the correlation is deemed perfect; for values of correlation coefficient $\mathrm{r}=+$ or -0.5 and above, the correlation is deemed high; for the values of correlation coefficient $\mathrm{r}=+$ or -0.25 to + or -0.5 , the correlation is deemed moderate; for the correlation coefficient $\mathrm{r}=$ below + or -0.25 , the correlation is deemed of low degree; while for values of coefficient $r=0$ depicts no correlation. On the other hand, the signs (either negative or positive) indicate the direction of the relationships (Blalock, 2012). This interpretation was applied on the analysis of data from table 9. 
Though the degrees of correlations were low, Extraversion was positively correlated to violence $(r=0.155)$. This implied that the participants who displayed higher levels of extraversion possessed higher tendencies to involvement in violence. In comparison to the other big five personalities, extraversion displayed the highest positive correlativeness to the involvement in violence. These findings were consistent with those of (Schmitt, 2011) who reported that Sexual promiscuity and violence were somewhat related to neuroticism and openness as well, but was more highly related to extraversion. Similarly, Nidhi and Prerna (2010) also reported that Risk taking was found to be minimal among introverts and maximum among extroverts.

At minimal degrees of correlation, Agreeableness was found to be negatively correlated to violence $(r=-0.101)$. This implied, increased levels of agreeableness among the participants tended to reduced levels of involvement in violence. These findings were consistent with those of (Vollrath, Knoch\&Cassano, 2012) which reported that the personality dimensions of Agreeableness and Conscientiousness had negative direct effects on perceptions of susceptibility as well as negative indirect effects through risky health behaviors. Similarly, (Chraif, Mihai, Vlad Burtăverde \& Teodor, 2015) also reported that aggressive driving (an example of violence) was negatively related to emotional stability, agreeableness, and conscientiousness.

At moderate degrees of correlation, Conscientiousness had strong negative correlation to violence $(r=-0.425)$. The participants who displayed more of conscientiousness were least likely to be involved in violence. These findings were supported by (Olalekan, 2014) who reported that the conscientiousness predicted personality safety of health risks. Similarly, (Chraif, Mihai, Vlad Burtăverde \& Teodor, 2015) also reported that aggressive driving (an example of violence) was negatively related to emotional stability, agreeableness, and conscientiousness.

At minimal degrees of correlativeness, Neurotic tendencies were found to be positively correlated with violence $(r=$ 0.102). The participants who displayed more of neuroticism tended to be more involved in violence. This may be attributed to have resulted from their disposition of traits like anxiety and panic. These findings on neuroticism were consistent with those of (Krista, Jeffrey, Henry \& Paul, 2002) who reported that Neuroticism facet of impulsivity indicated an inability to resist cravings and urges. Moreover, (Slavinskienea \& Matulaitieneb, 2016) reporting on the study aimed at identifying personality profiles in the sample of traffic offenders, indicated that those who had higher expression of impulsiveness, aggression and neuroticism (high risk personality profile), consume alcohol in a hazardous and harmful way. To add on, (Merritt \& Ian (2012) also reported that greater reckless risk taking behaviors were associated with high neuroticism and low conscientiousness.
At low degrees of correlativeness, Openness had a negative correlation to involvement in violence $(r=-0.187)$. Therefore participants who had high incidence to openness displayed decreased tendencies to involvement in violence. These findings were corroborated with those of (Erdinc \& Battaglio, 2015) who reported that Openness was important in the analysis of decision-making subjects, tasks and contexts. This may be attributed to the fact that open minded individuals have high imaginativeness and creativity, that their incidence to risk were circumstantial.

Upon testing the hypotheses $\mathbf{H}_{\mathbf{o}}$ and $\mathbf{H}_{\mathbf{A}}$, the 2-tailed significant levels in table 9 were used. The 2-tailed significant levels were then divided by two in order to obtain the directional significant levels for making decision on whether to accept or reject the null hypothesis $\mathbf{H}_{\mathbf{o}}$. The directional significant levels $(0.000,0.001,0.007,0.011,0.0115,0.014$, $0.020,0.021,0.035,0.045$ and 0.13 ) were found to be less than the set significant level $(0.05)$ hence the null hypothesis $\mathbf{H}_{\mathbf{o}}$ was rejected and the alternative hypothesis $\mathbf{H}_{\mathbf{A}}$ was accepted. The results were therefore generalized as: "There was a statistically significant relationship between the big five personality and involvement in violence". These findings were justified by the study conducted by (Lubomir \& Jana, 2015) who reported that personality was significantly related with acute risk taking in financial sector, banking sector and everyday life.

Generally, both qualitative and quantitative discussions on the relationship between the big five personality and involvement in violence converged in that they elaborately explained each other by providing similar findings on the relationship between the big five personality and involvement in violence. The coherency in the results may be attributed to the use of appropriate scientific procedures in the inquiry.

\section{CONCLUSION}

In conclusion, the big five personalities: extraversion, agreeableness, conscientiousness, neuroticism and openness were found to be correlated significantly to the involvement in violence. The participants who displayed higher levels of extraversion possessed higher tendencies to involvement in violence. In comparison to other big five personalities, extraversion displayed the highest positive correlativeness to the involvement in violence. Agreeableness was more negatively correlated to violence. This implied, increased levels of agreeableness among the participants tended to reduced levels of involvement in violence. Conscientiousness was more negatively correlated to violence. The participants who displayed more of conscientiousness were least likely to be involved in violence. Neurotic tendencies were more positively correlated to violence. The participants who displayed more of neuroticism tended to be more involved in violence. Openness had negative correlation to involvement in violence. Therefore to minimize involvement in violence, more interventional measures should be applied to people who display more of extraversion and neuroticism. 


\section{REFERENCES}

[1] Abd-Elwahab, M. \& Amin, M.E. (2012). Sexual risk among substance users and its relation to Personality profile. Egypt $\mathbf{J}$ Psychiatric, 12 (33), 135 - 141.

[2] Adrienne, T. \& Bichsel, J. (2014). Association between selfrated health and personality. US National Library of Medicine, National Institute of Health Ethn Autumn, 24 (4), 418 - 422.

[3] Alhakami, A.S. \& Slovic, P. (1994). A psychological study of the inverse relationship between perceived risk and perceived benefit. Risk Analysis, 14 (1), 1085-1096.

[4] Alvergne, A., Markus, J. \& Charlotte, F. (2010). Personality and testosterone in men from a high fertility population. Personality and individual difference Journal, 49 (10), 840-844.

[5] Anisi, J., Mohammad M., Mohsen J. \& Zahra G. (2010). Validity and reliability of NEO Five-Factor Inventory (NEO-FFI) on University students. International Journal of Behavioral Sciences, 5 (4), 300 - 389.

[6] Barbara, E. (2008). Personality theories: an introduction (8th ed.). Boston, MA: Houghton Mifflin.

[7] Benard, H. R., \& Ryan, G. W. . . (2010). analyzing qualitative data: systematic approaches.California, CA: Sage Publication.

[8] Bendassolli, P. (2013). Theory Building in Qualitative Research: Reconsidering the Problem of Induction. Journal of qualitative research, 14 (1), 25 - 31.

[9] Blalock, H. M. (2012). Social statistics. New York: McGraw-Hill.

[10] Botha, A. (2014, Sept). Islam Radicalization in Kenya Recruitment to al-Shabaab and the Mombasa Republican Council. ISS paper 265.

[11] Caroline, A. J., Marion Henderson John W. \& Frank Sally J. H. (2012). An overview of prevention of multiple risk behavior in Adolescence and young adulthood. J Public Health, 34 (1), 31-40.

[12] CDC Report (2015). Sexual Risk Behaviors: HIV, STD, \& Teen Pregnancy Prevention. US: Division of Adolescent and School Health, National Center for HIV/AIDS, Viral Hepatitis, STD and TB prevention.

[13] CDC Report (2011). Youth Risk Behavior Surveillance System. Retrieved from http://www.cdc.gov/healthyyouth/yrbs/pdf/us

[14] Chowdry, H. Elaine, K. \& Imran, R. . (2013). Reducing risky behavior through the provision of information. Institute for Fiscal Studies and UCL.

[15] Chown, P. Kezelman, C. \& Stavropoulos. P. (2012). Understanding Risk-Taking Behavior the last frontier: Practise Guidelines for Treatment of Complex Trauma and Trauma Informed care and Service Delivery. Sydney: ASCA.

[16] Coates, J. (2011). Behavioural strategies to reduce HIV transmission: how to make them work better. Los Angeles, CA: UCLA Program in Global Health, Division of Infectious Diseases, University of California.

[17] Collins, S.E. \& Carey, K.B. (2007). The theory of planned behavior as a model of heavy episodic drinking among college students. Psychol. Addict. Behav, 21, 498-507.

[18] Connelly, L. (2013). Demographic data in research studies. 22(4): 269. MedSurg Nursing, 22 (4), 269.

[19] Council of Governors Report (2017). Republic of Kenya Kisumu County First County Integrated Development Plan 2013-2017. Nairobi: Ministry of Devolution, Republic of Kenya.

[20] Creswell, J. (2014). Research design: quantitative, qualitative and mixed methods (4th ed.). London: SAGE Publications.

[21] Davies, J.G., Kendall, G., Soane, E., Charnley, J.L. \& Pollard, S.J. (2010). Regulators as agents: power and personality in risk regulation and a role for agent-based simulation. Journal of Risk Research, 13 (8), 961-982.

[22] Erdinc, F.R. \& Battaglio, J.P. (2015). Personality and decisionmaking in public Administration: the five-factor model in cultural perspective. International Review of Administrative, 3 (15), 12-23.

[23] Ertac, S. \& Gurdal, M.Y. . (2012). Personality, Group DecisionMaking and Leadership.

[24] Economic research forum (p. 1227). KOCUniversity-TUSIAD.
[25] Esther, D., Pascline, D. \& Kremer, M. (2010). Preventing HIV and teen pregnancy in Kenya: role of teacher training and education subsidies. Nairobi: Evaluation report in Kenya.

[26] Fischhoff, B., Slovic, P., Lichtenstein, S., Read, S., \& Combs, B. (2008). How safe is safe enough? A psychometric study of attitudes towards technology risks and benefits. Policy Sciences, 9, 127-152.

[27] Freudenstein, F.,Wiedemann, P.M. \& Varsier, N. (2015). Exposure Knowledge and Risk Perception of RF EMF. Front Public Health, 14 (2), 289.

[28] Galen, E.C., Holtgrave, D.R. \& Ríos, N.N. . (2014). Internal and External Factors That Encourage or Discourage Health-Rellevant Behavior. New York: MPH Behavioral Studies Section, CDC.

[29] Government Accountability Office, GAO (2017). Calculating and reporting survey response rates Internal guidance resource revised. Pp 1-11. US Government Accountability Office.

[30] Grant, C. \& Osanloo, A. (2014). Understanding, Selecting, And Integrating A Theoretical Framework in Dissertation Research: creating the blueprint for your house. Administrative issues Journal, 24 (2), 23-28.

[31] Guilford, J.P. \& Frucher, B. (2008). Fundamental statistics in psychology and education. New York: MC Graw-Hill.

[32] Hanlon, B. \& Larget, B. . (2011). Samples and Populations . Madison: Department of Statistics, University of Wisconsin.

[33] Hassan, H., Asad, S. \& Hoshino, Y. (2016). Determinants of Leadership Style in Big Five personality dimensions. Universal Journal of Management, 4 (4), 161-179.

[34] Hayden, J. (2009). Health Belief Model: Introduction to Health Behavior Theory. Sudbury, MA: Jones and Bartlett Publishers.

[35] Heine, J.S., Buchtel, E.E. \& Norenzayan, A. (2008). What Do Cross-National Comparisons of personality traits tell us? the case of conscientiousness. Psychological Science, 19 (4), 309-313.

[36] Holtzman, N.S. \& Strube, M.J. (2013). Above and beyond ShortTerm Mating, Long-Term mating is uniquely tied to human personality. Evol Psychol, 11 (5), 14-24.

[37] Hong, Y., Chao, M.M., Yang, Y.J. \& Rosner, J.L. (2010). Building and Testing Theories: experiences from conducting social identity research. Psychologica Sinica, 42 (1), 22-36.

[38] Hoyle, R.H., Michele, C.F., \& Miller, J.D. (2011). Personality and Sexual Risk Taking: A quantitative review. Journal of Personality, $6(8), 6-12$

[39] Horizon Program Impact (2014). ABC messages for HIV Prevention in Kenya: clarity and confusion, barriers and facilitator. Nairobi: USAID

[40] Irvine, M.J. \& Garner, D.M. (2011). Personality differences between hypertensive and normotensive individuals: influence of knowledge of hypertension status. Psychosomatic Medicine, 51 (5), 537-549.

[41] International Labour Oganization Report (2014). Accident prevention. In I. L. Oganization, Encyclopedia of occupational health and safety (p. 56). New York: ILO.

[42] Jackson, C.A., Henderson, M., Frank, J.W. \& Haw, J.S. (2012). An overview of prevention of multiple risk behavior in adolescence and young adulthood. J public Health, 34 (1), 31-40.

[43] John, O. P., \& Srivastava, S. (1999). The Big-Five trait taxonomy: History, measurement, and theoretical perspectives. In L. A. John, Handbook of personality: Theory and research (pp. 102-138). New York: Guilford Press.

[44] John, O.P., Robins, R. W. \& Pervin, L.A. (2014). Hand book on personality: Theory and research. New York: Guilford Press.

[45] Joshi, P. \& Bhardwaj, B.K. (2016). Personality Profile of Trait Consciousness of Male and Female sports persons. International Journal of Indian Psychology, 3 (4), 348-396.

[46] Juma, M., Askew,I., Jane Alaii, J., Kay, B.L. \& Borne, B.V. (2014). Cultural practices andsexual risk behaviour among adolescent orphans and non-orphans: a qualitative study on perceptions from a community in western Kenya. BMC Public Health, 4 (14), 84-89.

[47] Kagee, A. (2014). Identifying community risk factors for HIV among South African adolescents with mental health problems: A 
qualitative study of parental perceptions. Journal of Child and Adolescent Mental Health, 26 (3), 71-88.

[48] Kalmuss, D., Davidson, A., Cohall, A., Laraque, D. \& Cassell, C. (2013). Preventing Sexual Risk Behaviors and Pregnancy among Teenagers: Linking Research and Programs. London: Research and Programs.

[49] KDHS Report (2012). Kenya demographic health survey. Nairobi: Ministry of Health.

[50] Kenya Inter-Agency Rapid Assessment Report (2014). Kisumu secondary data review. Nairobi: KIRA.

[51] Kenya Demographic and Health Survey Report (2014). Demographic and Health Survey report.Nairobi: Kenya National Bureau of Statistics.

[52] Kenya AIDS Survey Indicator Report (2012). National AIDS Control Council. Retrieved from National AIDS Control Council: http://www.nacc.or.ke

[53] Kenneth, M. \& Cramer, K.M. (2013). Six Criteria of a Viable Theory: Putting Reversal Theory to test. Journal of Motivation, Emotion, and Personality, 1 (1), 9-16.

[54] Kibet, B. \& Wanjiku K. (2016, September Tuesday 6th). Strive to slay the dragon of tribalism in Kenya. Standard Digital .

[55] Krallis, D. \& Csontos, A. (2015). From Risk Perception to Safe Behavior. Australia: Deloite publications.

[56] Krista, K.J., Jeffrey, H.H., Henry, L.M. \& Paul, T.C. (2002). Personality path way to safe Sex:personality, condom use and HIV risk behaviours. Journal of personality, 36 (2), 117-133.

[57] Krzysztof B., Małgorzata A. B., Anna R., Katarzyna L., Dorota L.\& Alicja S. (2011). Smoking Status and the Five-Factor Model of Personality: Results of a Cross-Sectional Study Conducted in Poland. International Journal of Environmental Research and Public, 2 (45), 38-58.

[58] Lahey, B. (2010). Public Health Significance of Neuroticism. A psychological Journal (PMC), 64 (4), 241-256.

[59] Lambert, B.L. \& Bann, C.M. (2013). Risk-Taking Behavior among Adolescents with PrenatalDrug Exposure and Extra uterine Environmental Adversity. J Dev Behav Pediatric, 39 (4), 669-679.

[60] Lennart S., Moen, B.E. \& Rundmo, T. (2004). Explaining risk perception. An evaluation of the psychometric paradigm in risk perception research. Publikasjoner Rotunde : Norwegian University of Science and Technology, Department of Psychology.

[61] Leung, L. (2015). Validity, Reliability, and Generalizability in Qualitative Research. Journal of Family medicine primary care, 4 (3), 324-327.

[62] Lincoln,Y.S \& Lynham, S.A. (2013). Criteria for Assessing Good Theory in Human ResourceDevelopment and Other Applied Disciplines from an Interpretive Perspective. Singapore management Review, 27 (2), 1-24.

[63] Loew, J. (2011). Teens and Risky Sexual Behavior: What School Counselors Need to know. Wisconsin- stout: The graduate school, University of Wisconsin- stout.

[64] Lubomir, C \& Jana, C. . (2015). Risk preference under acute stress. Prague: Job talk.

[65] Luke, N. (2010). Risky Sex in Urban Kenya: The Bitter of Sugar Daddy Affair. Pop line Journa, 8 (4), 3-4.

[66] Lundström, M., Graneheim, U.H., Eisemann, M.E., Richter, J. \& Åström, S. (2012). PersonalityImpact on Experiences of Strain among Staff Exposed to Violence in Care of People with Intellectual Disabilities. Journal of policy and practice in intellectual disabilities, 4 (7), 30-39.

[67] Magu, D., Wanzala, P. \& Mutungi, M. (2013). Sexual risky behaviour and condom use Among Students in Kenyan universities. Advanced tropical medicine and public health journa, $3(1), 5-9$.

[68] Marshall, P. \& Samuels, E. (2020). Statistical Normality checking. Retrieved from http://www.statstutor.ac.uk

[69] Meehl, P. (2012). Construct validity in psychological tests Psychological Bulletin, 2 (52), 281-302.

[70] Merrit, C.J. \& Ian, J.T. (2012). Personality, Self Efficacy and Risk Taking in Porkuor. Avery Holl Campus, London: University of Greenwich.
[71] Mihaela C., Mihai A., Vlad B.\& Teodor M. (2015). The link between personality, aggressive driving, and risky driving outcomes - testing a theoretical model. Retrieved from http://www.DOI: 10.1080/13669877.2015.1042500

[72] Mohamed, S.F., Chimaraoke, I., Moore, M.N., Mutua, M., Kimani-Murage, \& Caroline Egesa,C. (2015). The estimated incidence of induced abortion in Kenya: a cross-sectional study. BMC Pregnancy Childbirth, 15 (15), 185-191.

[73] Morgan, H. S. (2007). Personality traits as risk factors for occupational injury in health care Workers. Florida: University of Florida.

[74] Mugenda \& Mugenda. (2008). Research methods. Retrieved from http:://www.researchbb.or.ke

[75] Muli, I., \& Lawoko, S. (2014). The Relationship between Access to Mass Media and HIV/AIDS Related Knowledge. Beliefs and Behaviors in Kenya Psychology, 4 (8), 736-743.

[76] Mwaura, K. (2009). HIV prevention strategies in Kenya. HIV/AIDS Journal, 29 (7), 544-568.

[77] Mwende, N. (2013). Introversion and Dating. Personality Journal, $6(7), 45-67$.

[78] Nasrollahi, B., Darandegan, K.B. \& Rafatmah, A. (2011). The Relationship between Personality traits and Sexual variety seeking. Procedia - Social and Behavioral Sciences, 30 (11), 13991402.

[79] National Council for Population and Development (2017). 2015 Kenya national adolescent and youth Survey. Nairobi: NCPD.

[80] Nation Media Group (2016, November Tuesday 10th ). Why drug abuse is on the rise among teens. Daily Nation News Paper, p. 45 .

[81] Ndegwa, N., Wanderi, M.P. \& A. Mwisukha. (2012). Factors Influencing Behavior Changefor the Prevention of the Spread of HIV/Aids among Students in Githunguri Division, Githunguri District, Kiambu County, Kenya. International Journal of Business and Social science, 3 (16), 313-321.

[82] Nidhi, S. \& Perna, P. (2010). Relationship between risk taking behaviour, personality and Sensation seeking tendencies among NCC cadets. 10sr Journals, 20 (5), 75-79.

[83] Njue, C., Voeten, H.A. \& Remes, P. (2011). Porn video shows, local brew, and transactional sexin Kisumu. Retrieved from BMC Public Health: http://www.localbrew_kenya.or.ke

[84] Omanyo, O. A. (2016). Personality as a Predictor of Involvement in Risky Sexual Behaviour: A Study Conducted Among Students in Secondary Schools in Nyakach Sub-county Kisumu County, Kenya. Advances in Social Psychology, 1 (1), 7-15.

[85] Olalekan, T. (2014). Personality, Self Efficacy and Health Anxiety as Predictor of Health Risk Behaviour among Scavengers in Ibadan. Scientific Research Journal, 2 (2), 5-14.

[86] Omanyo, A. (2016). Personality sub-types and involvement in risky sexual behavior Among students in secondary schools in Nyakach sub-county, Kisumu, Kenya. Nairobi: Faculty of Education at Catholic University of Eastern Africa.

[87] Omboto, J. (2013). Social Control and Crime Escalation in Kenya. International Journal of Research In social Sciences, 3 (3), 230247.

[88] Ondrej, K. \& Geckova, A.M. (2010). Psychological and behavioural factors associated with Sexual risk behaviour among Slovak students. BMC Public Health Journal, 9 (5), 1471-1475.

[89] Paunonen, S. V. \& Jackson, D. N. (2000). What is beyond the Big Five? Plenty! Journal of Personality, 68, 821-835.

[90] Reddy, S. (2002). Umthenthe Uhlaba Usamila - The South African Youth Risk Behaviour Survey. Cape Town: South African Medical Research Counci.

[91] Relief mobile phone application. (2018). Retrieved from Sample size calculator: http://www.nss.gov.au

[92] Richmond, J. (2014). Risky Behavior Programme. London: Children's Workforce Development Risky Behaviour Training Programme.

[93] Robbins, R.N.\& Bryan, A. (2004). Relationships between Future Orientation, Impulsive Sensation Seeking and Risk Behavior among Adjudicated Adolescents. Journal of Adolescent Research, 19 (40), 428-445. 
[94] Schmitt, P. (2004). The Big Five Related to Risky Sexual Behavior across 10 World Regions: Differential Personality Associations of Sexual Promiscuity and Relationship Infidelity. European Journal of Personality Eur. J. Pers., 18 (10), 301-319.

[95] Schmitt, P.D., Allik, J.,Robert R. McCrae, R.R \& Benet-Martinez, V. (2007). The Geographic Distribution of Big Five Personality Traits Patterns and Profiles of Human Self-Description across 56 Nations. Journal of Cross-Cultural Psychology, 38 (2), 173-212.

[96] Sec-Ed online magazine . (2014, March 6th). Retrieved from SecEd online magazine :http://www.sec-ed.co.uk.

[97] Serder, T. (2011). The Big Five Personality Traits and Risky Sport Participation: Ege University. Social Behaviour and Personality Journal, 39 (8), 1105 - 1112.

[98] Settles, R.E., Fischer, S. \& Melissa, A.C. (2012). Negative urgency; a personality predictor of externalizing behaviors characterized by neuroticism, low conscientiousness and disagreeableness. National Institute of Health (NIH) Public Access's Abnorm psychol., 121 (1), 160-172.

[99] Shakerian, A. \& Ali Mohammed, N. (2013). Investigating personality traits and premarital Affairwith opposite sex among university studentsof Sanandaj City. Procedia social and behavioral sciences Journal, 114 (21), 339-345.

[100] Shenton, K. (2004). Strategies for Ensuring Trustworthiness in Qualitative Research Projects. Education for Information, 22 (4), 63-75.

[101] Shillingburg, W. (2016). Understanding Validity and Reliability in Classroom, School-Wide, Or District-Wide Assessments to be used in Teacher/Principal Evaluations. Journal of behavioral education, 10 (4), 205-212.

[102] Slavinskienėa, J., Matulaitienèb, K.Z., Endriulaitienèc, A., \& Šeibokaite, L. (2016). Personality Profiles of Traffic Offenders: Does It Correlate To Alcohol Consumption? Health Psychology, 3 (5), 632-654.

[103] Slovic, P. \& Peters, E. (2005). "Affect, Risk, and Decision Making". Health Psychology, 24, 35-40.

[104] Steven M., Kogan, S.M.,Brody, G.H., Chen, Y.F., Grange, C.M., Slater, L.M. \& DiClemente, R.J. (2010). Risk and Protective Factors for Unprotected Intercourse among Rural African American Young Adults. Public Health Rep, 125 (5), 709-717.

[105] Sunday Nation. (2016, August 7th). High teen HIV, abortion rates fuel debate on sex education, p. 37

[106] SunYoun, L. \& Gakuin, M. . (2014). The Effects of Personality Traits and Behavioral Characteristics on Schooling, Earnings, and Career Promotion . OHTAKE Fumio: RIETI Discussion Paper Series University .

[107] Theorieënoverzicht, T.C.W. (2012). Health Belief Model explaining health behaviors. University of Twente publication.

[108] Terzian, A. \& Kristine, M. (2011). Preventing Multiple Risky Behaviors among Adolescents.London: Brief Publications.
[109] Terzian, S. (2011). Preventing Multiple Risky Behaviors among Adolescents. London: Seven Strategies.

[110] Turner, C. F. (2008). Adolescent Sexual Behavior, Drug Use, and Violence: Increased Reporting with Computer Survey Technology. Science Direcct, 280 (5365), 867-873.

[111] Uchudi, J., Magadi, M.\& Mohammod, M. (2010). A multilevel analysis of the determinants ofhigh risk sexual behavior (multiple sexual partners) in sub-Saharan Africa. London: Silver Spring, Maryland, U.S.A.2 Department of Sociology, City University.

[112] Udo-Akang, D. (2012). Theoretical Constructs, Concepts, and Applications. American International Journal of Contemporary Research, 2 (9), 89-111.

[113] Vollrath, M., Knoch, D. \& Cassano, L. (1999). Personality and perceived Susceptibility to health risks. European Journal of Personality Eur. J. Pers., 13 (9), 39-50.

[114] Voracek, M. (2009). Big Five Personality Factors and Suicide Rates in the United States:A State-Level Analysis. Percept Mot Skills, 109 (1), 208-212.

[115] Wambu, G.W. \& Fisher, A.T. (2015). School guidance and counseling in Kenya: Historical development, current status and future prospects. Journal of Education and Practise, 6 (11), 93102.

[116] Wang, W., Alva, S. \& Shanxiao, W. . (2012). DHS Analytical Studies No. 29 HIV-Related Knowledge and Behaviors among People Living with HIV in Eight High HIV Prevalence Countries in Sub-Saharan Africa. Maryland, USA: USAID: ICF International Calverton.

[117] WHO Report (2009). Environment and health risks: the influence and effects of social inequalities Report of an expert group meeting Bonn, Germany. Copenhagen Denmark : WHO Regional Office.

[118] WHO Report (2010). Alcohol use and sexual risk behavior: a cross-cultural study in eight Countries. WHO Library Cataloguing-in-Publication Data.

[119] WHO Report (2015). Risk assessment of the Ebola virus disease outbreak in West Africa. England: PHE Publications gateway number.

[120] Williams, J. etal. (2009). Violent and Antisocial Behaviors among Young Adolescents in Australian Communities: An Analysis Of Risk And Protective Factors . Murdoch: Centre for Adolescent Health, Murdoch Children's Research Institute for the Australian Research Alliance for Children and Youth.

[121] Wills, M.E. \& Melanie, M. . (2012). Theoretical Basis for Nursing . Philadelphia: Lippincott Williams and Wilkins.

[122] YosefJabareen, Y. (2009). Building a Conceptual Framework: Philosophy, Definitions, and Procedure. International Journal of qualitative research, 5 (8), 1-14. 